\title{
Factors Influencing Value Addition to Cashew Products Processed in the South-East Zone, Nigeria: A Multinomial Logistic Regression Approach
}

\author{
Anayochukwu Victor Eze, Ibrahim Macharia, and Lucy Ngare
}

\section{ABSTRACT}

\begin{abstract}
Nigeria is a leading cashew producer, but this has not been reflected in the development of the downstream cashew value chain industry. The launch of the "Agriculture Promotion Policy (2016 - 2020)" document was designed to encourage value addition to export crops such as cashew as ways of creating jobs and wealth to value chain actors. However, it is still unclear why cashew processors are unable to exploit this opportunity to improve value addition to cashew. This makes it imperative that factors influencing value addition to cashew products in the South-East zone, Nigeria be analysed. A crosssectional survey design involving a structured questionnaire was used to obtain data from 353 randomly selected respondents from the South-East zone, Nigeria. The findings from the multinomial logistic regression showed that income, access to market, product characteristics, and cost of cashew processing technology significantly influence value addition to cashew products in two models, whereas government policy on cashew processing and market facilities were significant in the second model. The relative risk ratios for age, educational level, income, processing experience, access to market, distance to market, government policy on cashew processing and market facilities were $>1$, suggesting the likelihood of processor's preferring to add value to cashew kernel, and both cashew products as against cashew nut for any unit increase in these variables. This study provided vital insights about how the relative significance of these factors will aid policy analysts and decision-makers to determine which of the factors to focus on while developing specific policies for the cashew value chain industry.
\end{abstract}

Keywords: cashew processor, discrete choice model, relative risk ratio, value addition.

\section{INTRODUCTION}

In recent decades, Nigeria has recorded a tremendous increase in the yearly cashew output with approximately $500,000 \mathrm{MT}$ in 2000, which has risen to almost one million MT in 2017 [1]. Consequently, Nigeria is now the leading producer of cashew nuts in Africa and ranks second at the world level after Vietnam [1], [2]. Nigeria accounts for nearly half of the African output (over 40 per cent) [3]. Africa contributes about 40 to 50 per cent of the world's cashew output. Apart from Nigeria, Cote d'Ivoire, Guinea-Bissau, Mozambique, and Tanzania are also notable for cashew production in Africa [4]. Nigeria's position in the global cashew production has not been reflected in the development of the downstream value chain industry. The bulk of the cashew nuts produced in the country are exported in their raw form because only very few individuals are involved in processing and value addition [5], [6].

Renewed attention has been given to the cashew crop in the last two decades because it is a highly-valued commodity with rising global market value [3]. The expectation is that the market will remain strong for a long time to come due to the huge global market potential for tradability of high-value cashew by-products, like cashew nutshell liquid (CNSL), cashew butter, cashew shell cake, and broken nuts [7]. Interestingly, the federal government trade policy of liberalizing export crops has had a considerable impact on the pricing and supply of unprocessed cashew nuts in Nigeria [8]. Nigeria still offers one of the cheapest sources of raw cashew nuts. Aliyu and Hammed [9] alluded to this by stating that Nigerian nut has constantly been used in Indian and Vietnamese cashew industries and more recently, added substantially to the Brazilian market.

The exports of the non-value-added products (raw nuts), as well as low export of value-added products (e.g., kernels), have been the major constraints to the development of the cashew value chain industry in Nigeria [10], resulting in poor foreign exchange earnings and loss of job opportunities. Nigeria still earns the least international premium from raw cashew nuts. Even the neighbouring. Republic of Benin earns 20 per cent price higher than Nigeria [11]. Small nuts, peelability, and poor post-harvest handling have been identified by USAID-Nigeria as the contributing factors to this low price. For instance, numerous flesh apples and nuts waste away in several cashew farms, simply because most of these producers lack the competence to sufficiently process 
cashew into more acceptable products for consumption as well as marketing at both local and international markets. Aliyu and Hammed [9] reported that 40-50 percent losses in cashew produce are attributed to poor post-harvest handling. This wastage leads to losses of livelihood and employment opportunities. No matter the case, Nigeria still has the potential to improve its price to at least the same level as her West African neighbours through value addition. Valueaddition can create opportunities for small to medium scale processors to take advantage of the growing demand for cashew products to create market niches.

Cashew remains a major export crop and source of livelihood to numerous smallholder farmers in the middle belt and southeastern zones of Nigeria [8, 11]. The South East, Nigeria remains the leading cashew-producing zone with four out of the five States making the list of the major producing States in Nigeria. The States are Enugu, Abia, Anambra, and Imo [12]. However, it is worrisome that despite being the country's hub of cashew production, processing and value addition activities remain at its lowest ebb. This is seen in the absence of the major large-scale cashew processing firms in the zone [13].

A typical cashew fruit comprises nut, kernel and apple. Thus, the processors' choice of which parts of cashew to add value is discrete. This makes the discrete choice model the most appropriate econometric tool for unravelling these factors. Discrete choice models remain one of the promising areas of research [14]. Discrete choices unlike actual choices make it possible to include features that have not been implemented, thus providing information about the potential effectiveness of various choice options. The models enable respondents to choose their preferred option and determine the influence of each attribute on their choice [14]. Some studies have used binary choice models to analyse discrete choice from a set of two discrete alternatives. Binary choice models of probit and logistic regressions have been used extensively for empirical analysis of discrete choice. For instance, Ngore [15] employed probit regression model on the ground that value addition decision is discrete and dichotomous to evaluate factors that influenced value addition to meat products in Kenya; Agwu et al. [16] used binary logit model to investigate the factors influencing value addition to cassava in Abia State, Nigeria.

Interestingly, the federal government of Nigeria has over the years come up with different agricultural policy interventions including the "Agriculture Promotion Policy (APP) (2016 - 2020)" document, which emphasizes value addition to export crops such as cashew as a way of creating jobs and wealth to value chain actors. However, it is still unclear why cashew processors are unable to exploit this opportunity to improve value addition to cashew. More so, extant literature shows that value addition factors have been examined in the leather industry, Kenya [17]; agricultural sector in selected developing countries with emphasis on human capital [18]; meat industry, Kenya [15]; cassava crop in Abia State, Nigeria [16]; dairy product in Welmera Woreda, Ethiopia [19]; and the closest dwelled on cashew farming households in Kogi State, Nigeria [6], which differs from the focus of this study. However, none of these studies examined factors influencing value addition to cashew products among cashew processors in the South East Zone,
Nigeria using the multiple choices model, which is the focus of this study. It is therefore imperative that these factors, which influence value addition to cashew products, be investigated. This will enable processors to concentrate on those factors with higher opportunities for improving returns from value-added cashew products. The findings will also serve as a guide for the development of specific policies for stimulating value addition to cashew products. Particularly, knowing the relative significance of these factors will aid policy analysts and decision-makers to determine which factors to focus on. This will also assist processors to contribute to food security and improve access to nutrition while benefiting from the economy of value addition by enabling them to capture higher profit margins from valueadded cashew activity.

\section{THEORETICAL FRAMEWORK}

The theoretical framework used in this study is the utility maximization theory. The proponents of this theory are $\mathrm{J}$. Bentham [20]; J.S. Mill [21]; and J.E. Crimmins and D.G. Long [22]. The theory is anchored on the assumption that the decision of cashew processors to add value to their products is influenced by expected utility and return, which ought to be higher if the processors add value to the products. The utility is compensated by the consumers through patronage. Thus, cashew processors will add value to their products if and only when they perceive the net benefits as a result of value addition will be greater than is the case without it. Although utility cannot be observed directly, however, the choices made by economic agents like the consumers can help in determining it.

Ultimately, the outcomes of value addition are to increase sales and profit maximization. This in turn will translate to an expansion of the enterprise, which ultimately leads to the employment of more labour while the exported products will enhance the foreign exchange earnings of the country. Overall, the theory is considered apt for this study because it is able to pinpoint that the underlying factor that motivates agribusiness entrepreneurs to add value to cashew products is profit. The theory is mathematically illustrated as follows:

Assuming that $U_{i}$ and $U_{k}$ stand for a cashew processor's utility for two choices, namely adding value ' $i$ ' and not adding value ' $k$ ', the linear random utility model for the two choices is stated thus:

$$
U i=\beta_{i} X_{i}+\epsilon_{i} \text { And } \quad U_{k}=\beta_{k}+\epsilon_{k}
$$

where $U_{i}$ and $U_{k}$ are expected utility from value-added and non-value added choices ' $i$ ' and ' $k$ ', $\beta_{i}$ and $\beta_{k}$ are the estimated parameters, while $\epsilon_{i}$ and $\epsilon_{k}$ are stochastic error terms considered to be autonomously identically distributed. If a cashew processor decides to choose choice $i$, it presupposes that the expected utility of adding value to choose $i$ is higher than that from choices (e.g., $k$ ). This is mathematically expressed as:

$$
U i\left(\beta_{i} X_{i}+\epsilon_{i}\right)>U_{k}\left(\beta_{k} X_{k}+\epsilon_{k}\right)
$$

The chance that the processor will prefer to add value, i.e., the choice ' $i$ ' can be stated as: 


$$
\begin{aligned}
& P(Y=1 \mid X)=P\left(U_{i}>U_{k}\right) \\
& P\left(\beta i X i+\epsilon_{i}-\beta_{k} X_{k}+C_{k}>0 \mid X\right) \\
& P\left(\beta i X i-\beta_{k} X_{k}+C_{i}-C_{k}>0 \mid X\right) \\
& P\left(X^{i} * X_{i}+C^{i *}>0 \mid X=F\left(\beta_{i} * X_{i}\right)\right.
\end{aligned}
$$

where ' $P$ ' is the probability function, $U_{i}$ and $U_{k}$ have been defined above, $C_{i}-C_{k}$ are random stochastic error term, $\beta^{\prime}$ is a vector of unknown parameter which represents the net influence of the predictor variables on the choice to add value, while $F\left(\beta^{\prime} X i\right)$ represents the cumulative distribution function of estimate ' $\beta$ ' $X i$ '. The precise distribution of ' $F$ ' depends on the distribution of the random error term. Based on the distribution of this error term, many other qualitative choice models can be estimated [23].

The theory is most appropriate for this study because it fits into the multinomial choice model that was used in this study. Multinomial logistic regression was employed to establish the correlation between a polytomous response variable and a set of predictor variables. The model was employed to elucidate discrete choices, i.e. when the number of choices available is more than two and is mutually exclusive [23], [24]. In other words, it is a model that is employed to forecast the chances of the various potential results of an unconditionally distributed response variable, considering the set of predictor variables (which could be binary-valued, categorical-valued, or real-valued).

\section{METHODOLOGY}

\section{A. Study Location}

The study was conducted in the South-East zone, Nigeria. The area is one of the six geo-political zones in Nigeria and comprises five States, namely Anambra, Imo, Abia, Enugu, and Ebonyi (Fig. 1). The area has a population of 16.4 million inhabitants, mostly Igbos [25]. It has a landmass of about $58,214.7 \mathrm{~km} 3$, the area lies between longitude $6050 I$ and 80 $30 I$ E latitude $4030^{I}$ and $705^{I} \mathrm{~N}$. South-East zone of Nigeria is bordered in the east by Cross-River State, Delta State in the west, Kogi and Benue States in the north and Akwa-Ibom and Rivers States in the south. The zone lies within the rainforest and derived savannah regions of Nigeria. Two main seasons characterize the zone: namely: rainy and dry seasons.

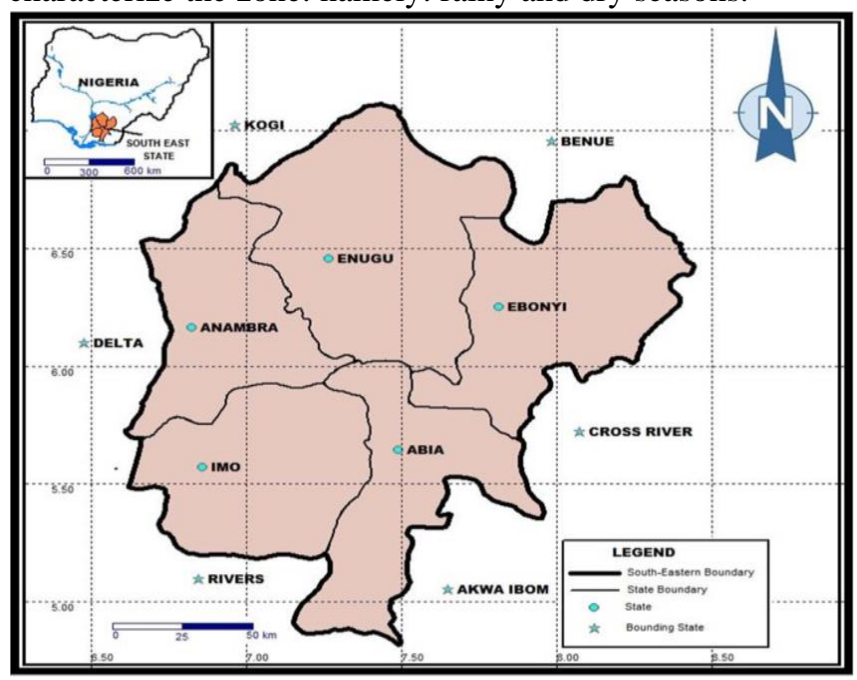

Fig. 1. Map of South East, Nigeria.
South-East zone, Nigeria is deemed appropriate for this study because of its antecedent as a major cashew producing zone with four out of the five States of the zone being among the major producing States in Nigeria [6], [10]. Historically, cashew was first introduced into the zone by the Portuguese merchants as a means of checkmating erosion. Since then, emphasis has shifted from the use of cashew as a crop for erosion control to economic plants with high potential for livelihood and income generation.

\section{B. Study Population}

The population of this study was made of the entire individuals involved in cashew processing in the South-East zone, Nigeria. Specifically, the population was drawn from the list of cashew processors obtained from the Agricultural Development Programme (ADP) of the sampled States. The processors operate mainly at small-scale levels. This is in line with the report of SBM Intelligence [13], which stated that the largest cashew processing firms in Nigeria have are located in Kwara, Kaduna, Ogun and Lagos. The ADP record shows the State-by-State population of cashew processors as follows Abia State - 13,221, Anambra State - 8,261, Enugu State $-23,820$ and Imo State $-15,735$. Thus, the total population of cashew processors in the study area is 61,037 .

\section{Sample Size Determination}

To ensure adequate representation for the entire population, the proportional sample size formula developed by Krejcie and Morgan [26] was adopted. Given that the sample frame is known, the construct is most appropriate for this study because it considered vital parameters for sample size determination like specific margin of error and the desired confidence interval. The formula as developed by Krejcie and Morgan is stated as:

$$
n=\frac{X^{2} x N x P(1-P)}{\left.M E^{2} x(N-1)\right)-\left(X^{2} x P x(1-P)\right)}
$$

where:

$\mathrm{n}=$ Sample size;

$\mathrm{X}^{2}=$ Chi-square for the specified confidence level at 1 degree of freedom;

$\mathrm{N}=$ Population size;

$\mathrm{P}=$ Population proportion;

$\mathrm{ME}=$ Desired Margin of Error (expressed as a proportion).

$$
\begin{gathered}
n=\frac{3.84 \times 61,037 \times 0.5(1-0.5)}{\left(5.2^{2 *}(61,037-1)+(3.84 \times 0.5(1-0.5))\right.} \\
n=\frac{58,595.52}{165.961344} \\
\mathrm{n} \approx 353
\end{gathered}
$$

Accordingly, the sample size of the study was determined as 353 .

\section{Sampling Technique}

A quantitative research design involving a cross-sectional survey was adopted for the study. This study adopted multistage random and purposive sampling techniques. In the first stage, four of the major cashews producing states in South East, Nigeria were purposively selected. This is based 
on the assumption that the availability of cashew will stimulate an individual's interest to engage in value addition activities in the area. Based on this, Abia, Anambra, Enugu, and Imo States were chosen. This also conforms to USAIDNigeria [10] designation of major cashew producing States in Nigeria. From the four States, one agricultural zone each was purposively selected to give a total of four (4) agricultural zones. This was based on the result of a reconnaissance survey that was conducted to identify the major cashew producing zones in each of the states as well as the concentration of cashew processors in the area. The third stage involved the random sampling of three hundred and fifty-three (353) cashew processors from the lists of processors that were obtained from ADP in the South-East zone, Nigeria (Table I).

The selection of the respondents was proportionately done using Bowley's proportionate allocation technique (equation 2 ). Bowley's proportionate allocation technique as quoted in Onwubiko et al. [27] is expressed as follows:

$$
n h \quad=\frac{n N h}{N}
$$

where:

$\mathrm{nh}=$ Number of questionnaire allocated to each State

$\mathrm{Nh}=$ Population size of each State;

$\mathrm{N}=$ Total sample size obtained (353);

$\mathrm{N}=$ Total population $(61,037)$.

\section{TABLE I: DISTRIBUTION OF POPULATION AND SAMPLED RESPONDENTS}

\begin{tabular}{ccc}
\hline State & $\begin{array}{c}\text { Sample frame of } \\
\text { processors }\end{array}$ & $\begin{array}{c}\text { No. of sampled } \\
\text { respondents }\end{array}$ \\
\hline Abia & 13,221 & 76 \\
Anambra & 8,261 & 48 \\
Enugu & 23,820 & 138 \\
Imo & 15,735 & 91 \\
Total & $\mathbf{6 1 , 0 3 7}$ & $\mathbf{3 5 3}$ \\
\hline
\end{tabular}

Source: Compilation of the ADP record in the sampled States.

\section{E. Source of Data and Instrument of Data Collection}

Data were sourced principally from a primary source. The data were obtained with a structured questionnaire that was administered in-person to the sampled respondents. The questionnaire was designed to elicit information related to the business strategic goals, socioeconomic attributes, product characteristics, and institutional factors affecting value addition to cashew products. These variables are listed in Table II. To facilitate effective distribution and retrieval of the questionnaire, four research assistants who were University graduates were selected and trained to ensure adequate coverage and effective collection of the needed information from the respondents. The criteria for selection and training of the research assistants were based on their knowledge of research activity.

\section{F. Data Analysis}

The data were extracted from the questionnaire and captured in an MS Excel worksheet using the assigned code for categorical variables and appropriate values for continuous variables. The data were analysed using Stata (version 13.1, StataCorp, Texas 77845, USA) tool. Specifically, multinomial logistic (MNL) regression was used to analyse the data.
TABLE II: DESCRIPTION OF PREDICTOR VARIABLES AND A PRIORI EXPECTATION

\begin{tabular}{|c|c|c|c|}
\hline $\begin{array}{l}\text { Variable } \\
\text { code }\end{array}$ & $\begin{array}{l}\text { Description of } \\
\text { variable }\end{array}$ & Method of measurement & $\begin{array}{l}\text { Expected } \\
\text { sign }\end{array}$ \\
\hline $\mathrm{X}_{1}$ & Age of the processor & $\begin{array}{l}\text { The age of the processors } \\
\text { will be measured in years }\end{array}$ & - \\
\hline $\mathrm{X}_{2}$ & $\begin{array}{l}\text { Membership of } \\
\text { cooperative society }\end{array}$ & Dummy $(1=$ yes, $0=$ no $)$ & + \\
\hline $\mathrm{X}_{3}$ & $\begin{array}{l}\text { Educational } \\
\text { attainment of the } \\
\text { processor }\end{array}$ & $\begin{array}{c}\text { Number of years spent } \\
\text { schooling }\end{array}$ & + \\
\hline $\mathrm{X}_{4}$ & $\begin{array}{l}\text { Monthly income } \\
\text { generated from } \\
\text { cashew processing }\end{array}$ & Amount in naira & + \\
\hline $\mathrm{X}_{5}$ & $\begin{array}{c}\text { Cashew processing } \\
\text { experience }\end{array}$ & Years & + \\
\hline $\mathrm{X}_{6}$ & $\begin{array}{l}\text { Access to credit for } \\
\text { cashew processing }\end{array}$ & Dummy $(1=$ yes, $0=$ no $)$ & + \\
\hline $\mathrm{X}_{7}$ & Type of market & $\begin{array}{c}\text { Dummy }(1=\text { village, } 2= \\
\text { urban, } 3=\text { regional, } 4= \\
\text { international, } 5=\mathrm{e}- \\
\text { market })\end{array}$ & + \\
\hline $\mathrm{X}_{8}$ & $\begin{array}{l}\text { Cashew product } \\
\text { characteristics }\end{array}$ & $\begin{array}{c}\text { Dummy }(1= \\
\text { perishability, } 2= \\
\text { peelability, } 3= \\
\text { breakability, } 4=\text { size, } 5= \\
\text { colour, } 6=\text { taste, } 7= \\
\text { aroma) }\end{array}$ & - \\
\hline $\mathrm{X}_{9}$ & $\begin{array}{c}\text { Perception of } \\
\text { processors about } \\
\text { government policy } \\
\text { on cashew } \\
\text { processing }\end{array}$ & $\begin{array}{c}\text { Dummy }(1=\text { favourable }, \\
2=\text { fairly favourable, } 3= \\
\text { unfavourable })\end{array}$ & + or - \\
\hline $\mathrm{X}_{10}$ & $\begin{array}{l}\text { Perception of } \\
\text { processor about cost } \\
\text { of processing } \\
\text { technology }\end{array}$ & $\begin{array}{c}\text { Dummy }(1=\text { very } \\
\text { expensive, } 2=\text { expensive, } \\
3=\text { fairly expensive, } 4= \\
\text { not expensive })\end{array}$ & + or - \\
\hline $\mathrm{X}_{11}$ & $\begin{array}{c}\text { Available } \\
\text { infrastructure for } \\
\text { marketing of value } \\
\text { added cashew } \\
\text { products }\end{array}$ & $\begin{array}{c}\text { Dummy }(1=\text { accessible } \\
\text { roads, } 2=\text { storage } \\
\text { facilities, } 3= \\
\text { telecommunication, } 4= \\
\text { electricity, } 5=\text { portable } \\
\text { water })\end{array}$ & + \\
\hline $\mathrm{X}_{12}$ & $\begin{array}{l}\text { Business strategic } \\
\text { goals of the } \\
\text { processor }\end{array}$ & $\begin{array}{c}\text { Dummy }(1=\text { profit } \\
\text { motive, } 2=\text { product } \\
\text { differentiation, } 3= \\
\text { increase share of market } \\
\text { sales) }\end{array}$ & + \\
\hline $\mathrm{X}_{13}$ & $\begin{array}{l}\text { Market distance from } \\
\text { the processing site }\end{array}$ & Kilometre & + or - \\
\hline
\end{tabular}

\section{G. Model Specification}

\section{1) Multinomial Logistic (MNL) Regression}

MNL regression is a model that is useful for predicting the probabilities of the varied possible outcomes from a categorically distributed dependent variable, given a set of predictor variables [23]. The predictor variables could be dichotomous/or binary, e.g., continuous (i.e., interval or ratio in scale) or polytomous (involving more than two categories of the response or outcome variable. MNL regression is often regarded as very attractive because it does not assume normality, homoscedasticity, and linearity [28]. MNL model is very useful for explaining discrete choices [24]. Berry [29] averred that an interesting feature of the MNL model is that the choice probabilities increase easily as the number of options increases. This feature makes the MNL model very applicable to discrete choice settings.

It is important to note that utility and choice are mainly deterministic from the cashew processor's behaviour. The assumption is that the choice decisions of adding value to 
specific cashew products are in stochastic random form. Some of the determinants of utility are unobservable, which suggests that the choice can only be determined in a probabilistic manner [23]. Therefore, to describe the choice decision, the processor's attributes and attributes of the cashew products that received value are considered. For every rational processor, his choice for a particular cashew product to add value must be such that the utility derived from it must exceed the utility derived from the reference or base category.

For a clear illustration of the multinomial logistic model, let ' $y$ ' be designed as the random variable which takes the values $\{1,2 \ldots . \mathrm{j}\}$ for choices $\mathrm{j}$, a positive integer, while ' $x$ ' represents a set of conditioning variables. In this regard, ' $y$ ' denotes the choice of value addition to cashew product in the South-East zone of Nigeria. Supposing every cashew processor has to choose from among the set of discrete, mutually exclusive choices of cashew products to add value (this implies that an individual precisely opts for one option out of many options, not more than or less than one). These measures appear to depend on factors of ' $x$ '. As a result, ' $x$ ' denotes a set of independent variables influencing value addition to cashew products. However, it is important to ask how, if all things are equal, variations in the component of ' $x$ ' can influence the response probabilities $\mathrm{p}(\mathrm{y}=\mathrm{j} / \mathrm{x}), j=1$, $2 \ldots . \mathrm{k}$. The likelihood that a processor ' $i$ ' will choose to add value to alternative product ' $j$ ' among the set of cashew products is expressed mathematically as:

$$
P(y=j / x)=P\left(U_{i j}>U_{i k} / x\right)
$$

where $U_{i j}$ and $U_{i k}$ are the perceived utilities by processor ' $i$ ' of choice of product value addition alternatives ' $j$ ' and ' $k$ ' correspondingly to $X_{I}$ being the vector of explanatory variables.

To elicit information on specific value addition activities on cashew, the processors were provided with a list of various cashew products that are produced from specific cashew part(s). The processors were asked to indicate the specific cashew part(s) that they add value to produce another form(s) of cashew product(s). From the responses of the cashew processors, the researcher was able to delineate two specific cashew parts that processors are adding value to, namely: cashew nut, and kernel. It was observed that the processors were not adding value to cashew apple and such it was eliminated from the model, however, those adding value simultaneously to cashew nut, and kernel form the third category of the response variable.

(i) Cashew nut: This category of processors captures those who are engaged in various value addition activities on raw cashew nut that yields products such as cashew nut testa, cashew nut oil cake, cashew cheese, cashew kernel, cashew butter, and cashew nutshell liquid (CNSL).

(ii) Cashew kernel: The options listed in this category include processors whose value addition activities on cashew kernel produce products like animal feed, lubricant, roasted cashew kernel, among others.

(iii) Both cashew products: This category comprises processors who engage simultaneously in adding value to cashew nut and kernel to yield products listed in (i) and (ii) above.

The MNL model has response likelihoods and is stated as follows:

$\operatorname{Pr}(Y i=j)=\frac{\exp \left(\beta_{j} X_{i}\right)}{1+\sum_{j=1}^{k} \exp \left(\beta_{j} X_{i}\right)} j=1,2,3$

where: $\beta_{j}=K-1, j=1,2,3$

For the reference category,

$\operatorname{Pr}(Y i=0)=\frac{1}{1+\sum_{j=1}^{k} \exp \left(\beta_{j} X_{i}\right)} j=0$

where $P\left(Y_{i=j}\right)$ denotes the probability of cashew processor to add value to any cashew products between $1,2,3 \operatorname{Pr}\left(\mathrm{Y}_{\mathrm{i}}\right.$ ${ }{ }_{0}$ ) is the probability of being in the reference category. The explicit function is stated as:

$Y_{i}=\operatorname{In}\left(P_{j} / P_{o}\right)=\beta_{0}+\beta_{1} X_{1}+\beta_{2} X_{2}+\beta_{3} X_{3}+\beta_{4} X_{4}+\beta_{5} X_{5}+\ldots .$.

$+\beta_{13} X_{13}+e i$

$\mathrm{Y}_{\mathrm{i}}=$ Probability to add value to cashew products $(\mathrm{i}=1,2$, 3)

where: $1=$ Cashew nut, $2=$ Cashew kernel, $3=$ Both cashew products; while the reference (base) category was chosen from the response variable with the highest frequency, which in this case, is the cashew nut.

\section{2) Relative risk ratio ( $R R R)$}

To determine the relative risk ratio (RRR) from the multinomial logistic model, having estimated a set of coefficients $-\beta^{(1)}$ and $\beta^{(2)}$, corresponding to each outcome as follows:

$\operatorname{Pr}(y=1)=\frac{e^{X \beta^{(1)}}}{e^{X \beta^{(1)}}+e^{X \beta^{(2)}}+e^{X \beta^{(3)}}}$

$\operatorname{Pr}(y=2)=\frac{e^{X \beta^{(2)}}}{e^{X \beta^{(1)}}+e^{X \beta^{(2)}}+e^{X \beta^{(3)}}}$

$\operatorname{Pr}(y=3)=\frac{e^{X \beta^{(3)}}}{e^{X \beta^{(1)}}+e^{X \beta^{(2)}}+e^{X \beta^{(3)}}}$

The model, however, is unidentified in the sense that there is more than one solution to $\beta^{(1)}, \beta^{(2)}$ and $\beta^{(3)}$ that leads to the same probabilities for $y=1, y=2$, and $y=3$. To identify the model, you arbitrarily set one of $\beta^{(1)}$ or $\beta^{(2)}$ to $0-$ it does not matter which. That is to say, if $\beta^{(1)}$ is arbitrarily set to ' 0 ', the remaining coefficient $\beta^{(2)}$ will measure the change relative to the $y=1$ group. If on the other hand, $\beta^{(2)}$ is set to ' 0 ', the remaining coefficient $\beta^{(1)}$ will measure the change relative to the $y=2$ group, and the same is applicable when $\beta^{(3)}$ is set to ' 0 '. The coefficients will differ because they have different interpretations, but the predicted probabilities for $\mathrm{y}=1,2$, and 3 will still be the same [23]. Therefore, whichever parameter is arbitrarily set; the solution will still be the same as the underlying model.

Setting $\beta^{(1)}=0$, the equations become:

$\operatorname{Pr}(y=1)=\frac{1}{1+e^{X \beta^{(2)}}+e^{X \beta^{(3)}}}$ 


$$
\begin{aligned}
& \operatorname{Pr}(y=2)=\frac{e^{X \beta^{(2)}}}{1+e^{X \beta^{(2)}}+e^{X \beta^{(3)}}} \\
& \operatorname{Pr}(y=3)=\frac{e^{X \beta^{(3)}}}{1+e^{X \beta^{(2)}}+e^{X \beta^{(3)}}}
\end{aligned}
$$

The relative probability of $\mathrm{y}=2$ to the base outcome is:

$\frac{\operatorname{Pr}(y=2)}{\operatorname{Pr}(y=1)}=e^{X \beta^{(2)}}$

Let's call this ratio the relative risk, and let's further assume that $\mathrm{X}$ and $\beta_{13}^{(2)}$ are vectors equal to $\left(\mathrm{X}_{1} ; \mathrm{X}_{2} ;::: ; \mathrm{X}_{13}\right)$ and $\left(\beta_{1}^{(2)}, \beta_{2}^{(2)} \ldots \ldots \beta_{13}^{(2)}\right)$, respectively. The ratio of the relative risk for a one-unit changes in $\mathrm{X}_{\mathrm{i}}$ becomes:

$\frac{e^{\beta_{1}^{(2)} X_{1}+\cdots+\beta_{1}^{(2)}\left(X_{1}+1\right)+\beta_{2}^{(2)}\left(X_{2}+1\right)+\cdots+\beta_{13}^{(2)} X_{13}}}{e^{\beta_{1}^{(2)} X_{1}+\cdots+\beta_{1}^{(2)} X_{1}+\beta_{2}^{(2)} X_{2}+\cdots+\beta_{13}^{(2)} X_{13}}}=e^{\beta_{i}^{(2)}}$.

Relative risk can be gotten by exponentiating the above multinomial equation to yield regression coefficients that are relative risk ratios for a unit change in the predictor variables [30]. Thus, the exponentiated value of a coefficient is the relative-risk ratio for a unit change in the corresponding variable (risk is measured as the risk of the outcome relative to the base outcome). The RRR of a coefficient indicates how the risk of the outcome falling in the comparison group compared to the risk of the outcome falling in the referent group changes with the variable in question. An RRR > 1 indicates that the risk of the outcome falling in the comparison group relative to the risk of the outcome falling in the referent group increases as the variable increases. In other words, the comparison outcome is more likely. An $\mathrm{RRR}<1$ indicates that the risk of the outcome falling in the comparison group relative to the risk of the outcome falling in the referent group decreases as the variable increases. In general, if the RRR $<1$, the outcome is more likely to be in the referent group.

\section{RESULTS AND DISCUSSION}

The multinomial logistic regression model used for determining factors influencing value addition to cashew products processed in South East zone of Nigeria was first subjected to preliminary checks to ensure adherence to the regression assumptions, in addition to enhancing the accuracy of the result. In this regard, the following assumptions' tests were carried out: heteroscedasticity, autocorrelation, and multicollinearity tests. The test of heteroscedasticity in the model as provided by the Breusch-Pagan test shows the Pvalue was 0.8807 which is greater than 0.05 . Therefore, it is concluded that the alternative hypothesis be rejected, and the null hypothesis accepted that the variance of the residuals is homogenous in the model. This confirms that the assumption of homoscedasticity was met. The autocorrelation test as given by the Durbin-Watson statistic was 2.4. The acceptable value of Durbin Watson Statistic is 2 but it permits a range of \pm 2 . This implies that the model is free of autocorrelation as such the assumption was not violated. The multicollinearity statistics as provided by the variance inflation factor (VIF) scores range from 1.02-2.21, which are far below 10 and the tolerance values $(0.45-0.98)$, defined by $1 /$ VIF are well above 0.2 (Table III). This suggests absence of multicollinearity in the model as such the assumption was met.

\begin{tabular}{ccc} 
TABLE III: VARIANCE INFLATION FACTOR (VIF) & \\
\hline Variable & VIF & $1 /$ VIF \\
\hline Household size & 2.21 & 0.45 \\
Product characteristics & 1.83 & 0.55 \\
Perception about Processing technology & 1.78 & 0.56 \\
Access to market & 1.34 & 0.75 \\
Processing technology & 1.29 & 0.78 \\
Monthly income & 1.26 & 0.79 \\
Age & 1.25 & 0.80 \\
Education level & 1.23 & 0.82 \\
Membership of cooperative & 1.10 & 0.91 \\
Access to credit & 1.08 & 0.93 \\
Distance to market & 1.05 & 0.96 \\
Market facilities & 1.03 & 0.97 \\
processing & 1.03 & 0.97 \\
Business strategic goal & 1.02 & 0.98 \\
Mean VIF & 1.32 & \\
\hline
\end{tabular}

From the result of the MNL regression, the Likelihood Ratio (LR) Chi-Square of 379.61 suggests that none of the independents' regression coefficients is equal to zero (Table IV). In other words, the model fits significantly better with these predictor variables than as an empty model (i.e., a model without independent variables). The p-value was significant $(\mathrm{p}$-value $=0.0000)$, confirming that there are factors influencing value addition to cashew products processed in South East zone, Nigeria. The probability of adding value to cashew products is the outcome variable in this MNL regression. The estimate gave rise to two replicates of explanatory variables, which represent two models estimated for the probability of (i) adding value to cashew kernel relative to cashew nut, and (ii) both cashew products relative to cashew nut.

The coefficients of age in the two models were positive but insignificant $(\mathrm{P}>0.05)$, suggesting that older processors have the likelihood of adding value to cashew kernel, and both cashew products by $1.9 \%$ and $4.3 \%$ respectively as opposed to cashew nut. The finding suggests that age increases the probability of adding value to cashew kernel, and both products relative to cashew nut. It is important to note that in Nigeria's traditional setting, age increases access to resources such as capital, family labour, equipment, building, land, etc. Besides, age comes with responsibilities of fending for oneself and catering for one's children and dependents. Consequently, it is expected that most of the middle-aged people are engaged in cashew processing in order to shoulder the responsibility of fending for themselves and catering for their dependents. The finding is in conformity with that of Ngore et al. [31] who found that increase in the age of butchers has the tendency of increasing value addition to meat products in Kenya.

The coefficients of education level in the two models were positive but statistically insignificant $(\mathrm{P}>0.05)$, indicating that improving the educational level of processors increases the probability of value addition to cashew kernel, and both cashew products relative to cashew nut by 0.5 and 0.2 percent respectively. The result suggests that educated processors are more likely to add value to cashew kernel, and both cashew products relative to cashew nut. A similar result has been credited to Ngore et al. [31] who reported that educational 
attainment has the tendency of increasing value addition to meat in Kenya. In the contrast, Berem et al. [32] reported that educational attainment of household head in Baringo district of Kenya will likely decrease value addition to honey. It is important to state that the effect of education thresholds on successful entrepreneurship is country specific [32]. For instance, Ngore et al. [31] reported that Kenya and Zimbabwe have secondary school education level as the threshold that can stimulate the growth of small and medium scale enterprises while in other sub-Saharan African countries including Nigeria, primary school education is considered adequate. Thus, the fact that many of the cashew processors in this study have primary and secondary education is considered adequate for successful value addition to cashew products.

TABLE IV: MNL RESULT OF FACTORS INFLUENCING VALUE ADDITION TO

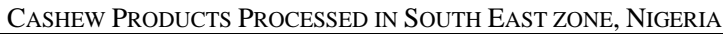

\begin{tabular}{|c|c|c|c|c|}
\hline Variable name & Coefficient & $\begin{array}{l}\text { Std. } \\
\text { Error }\end{array}$ & $\mathrm{Z}$ & $\mathrm{P}>|\mathrm{z}|$ \\
\hline Cashew nut & $\begin{array}{c}\text { (base } \\
\text { outcome) }\end{array}$ & & & \\
\hline \multicolumn{5}{|l|}{ Cashew kernel } \\
\hline Age & 0.019 & 0.032 & 0.59 & NS \\
\hline Educational level & 0.004 & 0.062 & 0.07 & NS \\
\hline Household size & -1.085 & 0.396 & -2.74 & $*$ \\
\hline Monthly income & 0.001 & 0.0005 & 2.34 & $* *$ \\
\hline Processing Experience & 0.009 & 0.052 & 0.18 & NS \\
\hline Access to credit & -0.694 & 0.821 & -0.84 & NS \\
\hline $\begin{array}{l}\text { Membership of } \\
\text { cooperative }\end{array}$ & 0.058 & 0.515 & 0.11 & NS \\
\hline Access to market & 2.782 & 0.387 & 7.18 & $*$ \\
\hline Distance to market & 0.035 & 0.036 & 0.96 & NS \\
\hline Product characteristics & 0.743 & 0.164 & 4.54 & $*$ \\
\hline $\begin{array}{l}\text { Govt. policy on } \\
\text { cashew proc. }\end{array}$ & 0.911 & 0.752 & 1.21 & NS \\
\hline $\begin{array}{l}\text { Perception about the } \\
\text { cost of processing } \\
\text { technology }\end{array}$ & -2.464 & 0.394 & -6.26 & $*$ \\
\hline Market facilities & 0.383 & 0.415 & 0.92 & NS \\
\hline $\begin{array}{l}\text { Business strategic } \\
\text { goals }\end{array}$ & -0.060 & 0.175 & -0.34 & NS \\
\hline Constant & 5.309 & 4.182 & 1.27 & NS \\
\hline Both cashew products & & & & \\
\hline Age & 0.043 & 0.030 & 1.42 & NS \\
\hline Educational level & 0.002 & 0.059 & 0.04 & NS \\
\hline Household size & -0.593 & 0.370 & -1.60 & NS \\
\hline Monthly income & 0.0001 & 0.00006 & 2.24 & $* *$ \\
\hline Processing Experience & 0.012 & 0.048 & 0.25 & NS \\
\hline Access to credit & -0.480 & 0.786 & -0.61 & NS \\
\hline $\begin{array}{l}\text { Membership of } \\
\text { cooperative }\end{array}$ & -0.425 & 0.489 & -0.87 & NS \\
\hline Access to market & 1.781 & 0.376 & 4.74 & $*$ \\
\hline Distance to market & 0.014 & 0.034 & 0.42 & NS \\
\hline Product characteristics & -0.448 & 0.167 & -2.69 & $*$ \\
\hline $\begin{array}{l}\text { Govt. policy on } \\
\text { cashew proc. }\end{array}$ & 1.826 & 0.915 & 2.00 & $* *$ \\
\hline $\begin{array}{l}\text { Perception about the } \\
\text { cost of processing } \\
\text { technology }\end{array}$ & -1.510 & 0.394 & -3.84 & $*$ \\
\hline Market facilities & 0.824 & 0.406 & 2.03 & $* *$ \\
\hline $\begin{array}{c}\text { Business strategic } \\
\text { goals }\end{array}$ & 0.012 & 0.166 & 0.07 & NS \\
\hline Constant & -5.552 & 4.370 & -1.27 & NS \\
\hline
\end{tabular}

Number of obs $=353$, LR chi2 $(28)=379.61$.

Pseudo $\mathrm{R}^{2}=0.5563$, Prob > chi $2=0.000$.

Log likelihood $=-151.391$

Note: $* * *$, and $* * *$ signify significant at $1 \%, 5 \%$, and $10 \%$ levels. NS indicates not significant.

The negative coefficients of household size in the two models imply that large household size decreases the likelihood of adding value to cashew kernel, and both cashew products relative to cashew nut by 108.5 and 59.3 percent respectively. The result confirms that processors with large family members are more likely to add value to cashew nut as against cashew kernel, and both cashew products. The finding contrasts that of Berem et al. [32], who reported that the coefficient of household size is positively correlated with the degree of value addition. Similarly, Agwu et al. [16] reported that large household size is positively correlated with the likelihood of adding value to cassava products in Abia State, Nigeria. Meanwhile, household size was significant $(\mathrm{P}<0.05)$ in the first model but insignificant $(\mathrm{P}>0.05)$ in the second model, suggesting that household size significantly influences value addition to cashew kernel. This may be due to the higher labour requirement of processors adding value to cashew kernel.

The coefficients of monthly income in both models were positive, which is an indication that high-income generation has the likelihood of increasing cashew processors decision to add value to cashew kernel, and both cashew products relative to cashew nut by 0.013 percent respectively. Monthly income also showed statistically significant $(\mathrm{P}<0.05)$ in the two models, signifying that it has a significant influence on value addition to cashew products. The finding suggests that income is a major determinant of value addition to cashew products. This is in conformity with that of Okebiorun and Jatto [34] who reported that income has a positive and significant effect on cassava value addition among women processors. Similarly, Agwu et al. [16] found income to be highly correlated with the likelihood of adding value to cassava products in Abia State, Nigeria. The need to earn higher income drives many processors to add value to cashew products. This view was also corroborated by Coltrain et al. [35] who submitted that the desire to increase income generation from agricultural produce has motivated several farmers to seek more creative ways of improving value addition to their products. Fleming [36] noted that value addition is particularly critical because it offers a strategy for transforming unsuccessful agro-enterprise into a successful one. Thus, high-income earning can influence value addition to cashew products because value added cashew products guarantee higher consumer's patronage which sustains higher revenue.

The coefficients of processing experience in both models although statistically insignificant $(\mathrm{P}>0.05)$ were positive. This implies that an increase in processing experience increases the probability of value addition to cashew kernel, and both cashew products relative to cashew nut by 0.95 and 1.2 percent relatively. The finding disagrees with that of Kehinde and Aboaba [37] who reported that the processing experience of cassava processors in Southwest Nigeria is inversely related to value added cassava products. Similarly, Adeyemo and Okoruwa [38] reported that a higher processing experience decreases the prospect of adding value to cassava products. Meanwhile, the finding agrees with that of Okebiorun and Jatto [34] who found processing experience to be significant and positively correlated with the probability of value addition to cassava among women processors.

Access to credit has negative coefficients and statistically insignificant $(\mathrm{P}>0.05)$ in both models, suggesting that improving processors' access to credit decreases the probability of adding value to cashew kernel, and both 
cashew products relative to cashew nut by 69.4 and 48.0 percent respectively. In other words, access to credit is more likely to increase value addition to cashew nut as against cashew kernel, and both cashew products. This finding concurs with that of Mkandawire and Gathungu [39] who reported that access to credit decreases the likelihood of farmer groups' participation in value addition activities in Malawi. In contrast, Ntale, Litondo and Mphande [40] found that access to credit has significant and positive influence on the probability of farmers adding value to farm produce.

The positive coefficient of membership of cooperative society in the first model implies that it has the likelihood of increasing value addition to cashew kernel as against cashew nut by 5.8 percent. However, the negative coefficient in the second model suggests that it decreases the probability of adding value to both cashew products relative to cashew nut by 42.5 percent although both models were insignificant $(\mathrm{P}>0.05)$. This divergent finding may be attributed to the fact that many of the cashew kernel processors belong to the cooperative, which provided platform for information and knowledge sharing. This coincides with the finding of Berem et al. [32] who found out that membership of cooperative positively influences farmers' participation in value added activity. But contrary to that of Okebiorun and Jatto [34] who reported that membership of cooperative society negatively influences the likelihood of women processors adding value to cassava.

The positive coefficients of access to the market in both models mean that expanding the number of markets accessible by processor increases the likelihood of adding value to cashew kernel, and both cashew products relative to cashew nut by 278 , and 178 percent respectively. More so, access to market for both models was statistically significant $(\mathrm{P}<0.05)$, suggesting it has a significant influence on value addition to cashew products. The finding is in tandem with that of Tsalwa and Theuri [41] who found that the type of market dealer access influences the degree of value addition.

The finding suggests that the extent of value addition to cashew products is determined by market destination. The specifications of buyers in the market(s) destination where cashew products are to be marketed determine to a reasonable extent the nature and degree of value be added to the products. The reason is that cashew product attributes preferred by buyers vary across market destinations where they are domiciled. Thus, cashew product attributes preferred by consumers located in rural market may differ from that of a consumer located in urban market. The observed consumer's cashew product attributes are factored into the value addition processes to reflect the consumer's product desirability in the market. Tsalwa and Theuri [41] corroborated this view by stating that market destination determines the degree and extent of value addition to products. This is mainly due to the preferences and tastes of consumers in the products' market destination. Improving processors access to the market can increase investment in cashew value addition activities while enhancing their resourcefulness in meeting diverse consumers' tastes and preferences.

The positive coefficients of distance to market although insignificant $(\mathrm{P}>0.05)$ in both models imply that one kilometer increase in distance to market increases the probability of adding value to cashew kernel, and both cashew products relative to cashew nut by 3.5 , and 1.5 percent respectively. The result indicates that distance to the marketplace positively influences cashew processors decision to add value to cashew kernel, and both cashew products. Distance to market could motivate cashew processor to add value to his/her products as a way of recouping the cost associated with transporting the products through the long distance to the marketplace. Corroborating this finding, Ntale et al. [40] found that distance to market has a significant and positive influence on the likelihood of farmers to add value to their produce. Mkandawire and Gathungu [39] also reported that distance to the market increases the likelihood of farmer groups' participation in value addition activities in Malawi.

Product characteristics have positive coefficient in the model with the probability of adding value to cashew kernel, and statistically significant $(\mathrm{P}<0.05)$, implying that improving cashew product characteristics increases the likelihood of adding value to cashew kernel relative to cashew nut by 74.3 percent. Consumers' desire for cashew kernel with certain desirable characteristics may have given rise to this result. However, the negative coefficient of product characteristics in the second model means that it decreases the likelihood of value addition to both cashew products as against cashew nut, but significantly influences value addition to both cashew products $(\mathrm{P}<0.05)$. Studies have shown that product characteristics influence consumer's purchasing decisions [42], [43]. Understanding how these product characteristics influence consumer's preferences and patronage of a product could lead to the development of more acceptable cashew products. Employing a technique that focuses on the improvement of these product characteristics may lead to the processing of high valued cashew products with greater consumer's acceptance and patronage.

The coefficients of processors' perception about government policy on cashew processing were positive in the two models. This implies that favourable processors' perception about government policy on cashew processing is likely to increase value addition to cashew kernel, and both cashew products as opposed to cashew nut by 91.1 , and 182.6 percent respectively. Meanwhile, the coefficients of processors' perception about government policy on cashew processing were significant $(\mathrm{P}<0.05)$ in the second model, confirming that it has a significant influence on value addition to both cashew products. The finding concurs with that of Tsalwa and Theuri [41] who reported that government policy is positively correlated with value addition to tea in Kenya. The finding obviously shows the need for government to initiate and pursue policies that will serve as incentives for motivating individuals to engage in cashew value addition activities. Alluding to the above assertion, Madura [44] opined that it is the sole responsibility of the government to create a conducive atmosphere for optimal growth and development of economic activities. It is therefore important that government policy on cashew processing should be favourably enough to impress positive perception on the processors so as to encourage greater value addition activities to cashew products.

The coefficients of processors' perception about cost of processing technology were significant $(\mathrm{P}<0.05)$ and negative for both models. The negative coefficients imply 
that processors perceive the cost of cashew processing as unfavourable as such diminishes the probability of adding value to cashew kernel, and both products with referent to cashew nut by 246.4 , and 151 percent respectively. The high cost of many modern processing technologies may have given rise to this result. However, the statistically significant $(\mathrm{P}<0.05)$ implies that processors' perception about the cost of cashew processing technology has a significant influence on value addition to cashew products. In a related study, Falola et al. [45] averred that farmers who have processing equipment are more likely to add value to their products than those who have not.

Market facilities showed positive coefficients in both models, indicating that increased provision of market facilities increases the likelihood of value addition to cashew kernel, and both cashew products relative to cashew nut by 38.3, and 82.4 percent respectively. More so, the coefficient of market facilities in the second model - at both cashew products was significant $(\mathrm{P}<0.05)$, confirming that market facilities significantly influence value addition to both cashew products. Availability of market infrastructure is crucial for enhancing value addition to cashew products. In the words of Admassie [46], a well-functioning market infrastructure creates economic opportunities that encourage processors to specialise in adding value to agricultural commodities that they have a competitive advantage. This finding is in agreement with that of Ntale et al. [40] who found that the availability of electricity increases the likelihood of value addition to tea in Kenya. Furthermore, Ismail [47] found that market infrastructure was significantly and positively correlated with small-scale farmers' decision to participate in market services.

The negative coefficient of business strategic goals in the first model implies that it decreases the probability of value addition to cashew kernel relative to cashew nut by $6 \%$. Whereas the positive coefficient in the second model suggests that business strategic goals increase the likelihood of adding value to both cashew products as against cashew nut by $1.2 \%$. However, the coefficients of business strategic goals were insignificant $(\mathrm{P}>0.05)$ in both models. Obviously, the result from the second model suggests that expanding business strategic goals can provide room for greater value addition to both cashew products than in cashew nuts. This finding agrees with that of Tsalwa and Theuri [41] who reported a significant and positive correlation between business strategy and the likelihood of adding value to tea in Kenya.

\section{1) Relative risk ratio ( $R R R)$}

The estimates from the multinomial logistic regression were further subjected to relative risk ratio analysis. According to Gallis and Turner [48], the relative risk ratio is a measure of the relative association between the independent variable(s) and the response variable. The essence is to determine the ratio of probability at which the processor could choose to add value to the outcome categories (cashew kernel, and both cashew products) over the probability of choosing to add value to the baseline/reference category (cashew nut).

The relative risk ratios (RRRs) from the two models show age (1.02 and 1.04), an education level (1.01 and 1.00), monthly income (1.0 and 1.0), processing experience (1.01 and 1.01), access to market (16.15 and 5.94), distance to market (1.035 and 1.015), processors' perception about government policy (2.487 and 6.208) and market facilities (1.47 and 2.28) were greater than 1 (Table V). This implies that any unit increase in any of these variables increases processors' preference to add value to cashew kernel, and both cashew products are as opposed to cashew nuts. In other words, the choice of adding value to cashew kernel and both cashew products over cashew nut increases with increase in age, education level, monthly income, processing experience, access to market, distance to market, processors' perception about government policy, and market facilities.

TABLE V: RRR OF FACTORS INFLUENCING VALUE ADDITION TO CASHEW PRODUCTS PROCESSED IN SOUTH-EAST ZONE, NIGERIA

\begin{tabular}{|c|c|c|c|c|}
\hline Value added product & RRR & Std. Error & $\mathrm{Z}$ & $\mathrm{P}>|\mathrm{z}|$ \\
\hline Cashew nut & $\begin{array}{c}\text { (base } \\
\text { outcome) }\end{array}$ & & & \\
\hline \multicolumn{5}{|l|}{ Cashew kernel } \\
\hline Age & 1.019 & 0.0347 & 0.59 & NS \\
\hline Education level & 1.005 & 0.062 & 0.07 & NS \\
\hline Household size & 0.338 & 0.134 & -2.74 & $*$ \\
\hline Monthly income & 1.0001 & 0.00006 & 2.34 & $* *$ \\
\hline Processing experience & 1.009 & 0.053 & 0.18 & NS \\
\hline Access to credit & 0.499 & 0.410 & -0.84 & NS \\
\hline Membership of coop. & 0.944 & 0.486 & -0.11 & NS \\
\hline Access to market & 16.150 & 6.256 & 7.18 & $*$ \\
\hline Distance to market & 1.035 & 0.037 & 0.96 & NS \\
\hline Product characteristics & 0.475 & 0.078 & -4.54 & $*$ \\
\hline $\begin{array}{l}\text { Perception about Govt. } \\
\text { policy }\end{array}$ & 2.487 & 1.870 & 1.21 & NS \\
\hline $\begin{array}{l}\text { Perception about cost } \\
\text { of processing } \\
\text { technology }\end{array}$ & 0.085 & 0.033 & -6.26 & $*$ \\
\hline Market facilities & 1.466 & 0.608 & 0.92 & NS \\
\hline $\begin{array}{c}\text { Business strategic } \\
\text { goals }\end{array}$ & 0.942 & 0.165 & -0.34 & NS \\
\hline Constant & 202.22 & 845.68 & 1.27 & NS \\
\hline Both Cashew Products & & & & \\
\hline Age & 1.044 & 0.0318 & 1.42 & NS \\
\hline Education level & 1.002 & 0.059 & 0.04 & NS \\
\hline Household size & 0.553 & 0.204 & -1.60 & NS \\
\hline Monthly income & 1.0001 & 0.00006 & 2.24 & $* *$ \\
\hline Processing experience & 1.012 & 0.048 & 0.25 & NS \\
\hline Access to credit & 0.619 & 0.486 & -0.61 & NS \\
\hline Membership of coop. & 0.654 & 0.320 & -0.87 & NS \\
\hline Access to market & 5.935 & 2.232 & 4.74 & $*$ \\
\hline Distance to market & 1.015 & 0.035 & 0.42 & NS \\
\hline Product characteristics & 0.639 & 0.107 & -2.69 & $*$ \\
\hline $\begin{array}{l}\text { Perception about Govt. } \\
\text { policy }\end{array}$ & 6.208 & 5.679 & 2.00 & $* *$ \\
\hline $\begin{array}{l}\text { Perception about cost } \\
\text { of processing } \\
\text { technology }\end{array}$ & 0.221 & 0.087 & -3.84 & $*$ \\
\hline Market facilities & 2.279 & 0.924 & 2.03 & $* *$ \\
\hline $\begin{array}{c}\text { Business strategic } \\
\text { goals }\end{array}$ & 1.012 & 0.168 & 0.07 & NS \\
\hline Constant & 0.004 & 0.017 & -1.27 & NS \\
\hline
\end{tabular}

Number of obs $=353$, LR chi2(28) $=379.61$.

Pseudo $\mathrm{R}^{2}=0.5563$, Prob > chi $=0.0000$.

Log likelihood $=-151.391$.

The RRRs from the two models for household size $(0.34$ and 0.55$)$, and cashew product characteristics (0.48 and 0.64) were $<1$. This implies that there is less likely that a processor chooses to add value to cashew kernel, and both cashew products as opposed to cashew nut as these variables increase. Thus, a processor with large household size and desirable cashew products' characteristics are more likely to add value to cashew nut relative to cashew kernel, and both cashew products.

The relative risk ratio for comparing processors with access to credit to those without access to credit preferring to 
add value to cashew kernel, and both cashew products, as opposed to cashew nut, is expected to decrease by factors of 0.50 and 0.62 respectively. Equally, the RRRs for comparing members of cooperative society to non-members for preferring to add value to cashew kernel, and both cashew products, as opposed to cashew nut, are expected to decrease by factors of 0.94 and 0.65 respectively. The relative risk ratios for comparing processors who perceived the cost of cashew processing technology to be expensive as against those who perceived it to be inexpensive for preferring to add value to cashew kernel, and both cashew products, as opposed to cashew nut, are expected to decrease by 0.09 , and 0.22 factors respectively. Obviously, the result indicates that processors who hold the perception that the cost of cashew processing technology is expensive are more likely to add value to cashew nut over and against cashew kernel, and both cashew products.

The relative risk ratio for processors whose business strategic goal favours value addition to cashew kernel over cashew nut decreases by a factor of 0.94 as against the relative risk of adding value to both cashew products that increases by 1.01 factor. The finding implies that the business strategic goal is more likely to influence processors' decision to add value to cashew nut, and both cashew products over and above cashew kernel.

\section{CONCLUSION}

The study established that income, access to market, product characteristics, government policy on cashew processing and cost of processing technology have a significant influence on value addition to cashew products, as such are the factors influencing value addition to cashew products processed in South East, Nigeria. Equally, the study found that the relative risk ratio for a unit increase in age, educational level, income, processing experience, access to market, distance to market, government policy on cashew processing and market facilities increases processor's preferred choice of adding value to cashew kernel, and both cashew products as oppose to cashew nut. The implication is that improving any of these factors will enhance value addition to cashew products. Thus, the study advocates that adequate priority should be given to these factors when considering a specific policy for the development of the cashew value chain industry in Nigeria.

\section{RECOMMENDATIONS}

Based on the foregoing, the study recommends:

1) Processors are encouraged to explore access to a wider range of markets for marketing cashew products as a way of increasing income generation.

2) Governments should ensure that markets located within locations with a high volume of cashew processing activities have adequate market facilities such as motorable roads, processing and storage equipment, telecommunication among others as a way of enhancing value addition to cashew.

3) Government should commission research for the development of cashew variety with characteristics that influence value addition. The programme should include a strategy for getting cashew producers to grow and gradual replacement of old stock with the released new variety.

4) Government should consider subsidizing cashew processing equipment and machinery to make it affordable to processors, to increase access and use of such equipment for cashew value addition.

5) The Federal Government of Nigeria should come up with a specific cashew policy for driving value addition programmes across the cashew value chain. This policy will serve as a stimulant for increasing investment in value addition to the cashew, thereby repositioning the Nigerian cashew industry from that of a low-priced commodity to supplier and exporter of high-quality value-added cashew products.

\section{ACKNOWLEDGMENT}

The authors are grateful to the academic staff of the Department of Agricultural Economics, Kenyatta University for their invaluable contributions that made this research a success. More so, we sincerely appreciate the entire Coordination team of the ACADEMY Project, an IntraAfrica Academic Mobility Scheme sponsored by the European Commission in partnership with the Africa Union for awarding a scholarship to the first author and for providing support fund for this research. Finally, our gratitude goes to the respondents for accepting to provide the needed data and the research assistants for being diligent in collecting the data used for this research.

\section{CONFLICT OF INTEREST}

We the authors declare there is no conflict of interest.

\section{LIST OF ABBREVIATIONS}

ADP Agricultural Development Programme

APP Agriculture Promotion Policy

CNSL Cashew nut shell liquid

MNL Multinomial logistic

NPC National Population Commission

RRR Relative risk ratio

SDG Sustainable Development Goal

USAID United States Agency for International Development

VIF Variance inflation factor

\section{REFERENCES}

[1] FAOSTAT. FAO country statistics; Crop. Available: http://www.fao.org/faostat/en/\#data/QC. Retrieved on 28th march, 2019.

[2] Adegbola, Y.P., Adjovi, N.R.A., Adekambi, S.A., Zossou, R. Sonehekpon E.S., Komlan, F.A. and Djossa, E. Consumer Preferences for Fresh Tomatoes in Benin using a Conjoint Analysis. Journal of International Food \& Agribusiness Marketing, 2019;31(1), 1-21. DOI: 10.1080/08974438.2018.1469448.

[3] FAOSTAT. Food and Agriculture Organization Statistics, 2013. Available online.

http://faostat.fao.org/site/567/DesktopDefault.aspx?PageID=567\#anco r.

[4] Adeigbe, O. O., Olasupo, F. O., Adewale, B. D. and Muyiwa, A. A. A review on cashew research and production in Nigeria in the last four decades. Scientific Research and Essays, 2015;10(5), 196-209. 
[5] Agbongiarhuoyi, A.E., Aigbekaen, E.O. and Akinbile, L.A. Awareness of cashew products potentials and market information among farmers in Kogi State, Nigeria. ARPN Journal of Agricultural and Biological Science, 2008;3(4), 10-16.

[6] Lawal, J.O., Oduwole, O.O., Shittu, T.R. and Muyiwa, A.A. Profitability of value addition to cashew farming households in Nigeria. African Crop Science Journal, 2011;19(1), 49-54.

[7] Boillereau, N. and Adam, B. Cashew processing, marketing and consumption in West Africa: current status and opportunities. WATH/Accra Technical Report No. 22, United States Agency for International Development $\quad-\quad$ USAID, 2007. http://www.watradehub.com/sites/default/files/resourcefiles/aug09/22 20cashew20retail20market20study20dec2007.pdf. Accessed on 28 October 2019.

[8] Topper, C.P., Caligari, P.D.S., Camara, M., Diaora, S., Djaha, A., Coulibay, F., et al. West African Regional Cashew Survey Report (Guinea, Guinea Bissau, Cote D'Ivore, Ghana and Nigeria). Sustainable Tree Crop Programme (STCP) and Biohybrids Agrisystem Ltd. U.K. 2001;1:110.

[9] Aliyu, O.M. and Hammed, L.A. Nigerian cashew economy: A review of nut production sector. Paper presented at the International Academy of African Business and Development (IAABD) Conference, University of Florida, Gainesville, USA, May 2008; 20-24.

[10] United States Agency for International Development (USAID)Nigeria. Industry Action Plan Nigerian Cashews. NW Washington DC: Chemonics International Inc., 2002.

[11] Central Bank of Nigeria (CBN). CBN Annual Report \& Statement of Accounts for the Year, 2005. http://66.40.18.146/search/runsearch.asp.

[12] Salau, S. A., Popoola, G. O. and Nofiu, B. N. Analysis of cashew nuts marketing in Kwara State, Nigeria. FUOYE Journal of Agriculture and Human Ecology, 2017;1(1), 34-44.

[13] SBM Intelligence. Nigeria's unrealised agricultural prowess: The case of cashew. A report by SBM Intelligence, 2016. Retrieved from www.sbmintel.com on 07 Jan, 2019.

[14] Kruk, M.E., Johnson, J.C., Gyakobo, M., Agyei-Baffour, P., Asabir, K., Kotha, S.R., et al. Rural practice preferences among medica students in Ghana: a discrete choice experiment. Bulletin of the World Health Organization, 2010;88, 333-341. doi: 10.2471/BLT.09.072892.

[15] Ngore, P. M. Evaluation of factors influencing value addition by butchery agribusinesses in Igembe north district, Kenya. MSc Thesis Submitted to the Graduate School, Egerton University, 2010.

[16] Agwu, N. M., Anyanwu, C. I. and Kalu, U. H. Factors influencing cassava value addition by rural agribusiness entrepreneurs in Abia State, Nigeria. Scientific Papers Series Management, Economic Engineering in Agriculture and Rural Development, 2015;15(3), 1924

[17] Mokhothu-Ogolla, P. and Wanjau, K. Factors affecting value addition in the leather industry in Kenya. European Journal of Business and Innovation Research, 2013;1(3), 45-55.

[18] Badri, A. K., Tabrizi, Y. E. and Badri, P. K. Factors Affecting the Value Added of Agriculture Sector in Selected Developing Countries Emphasising on Human Capital. Noble International Journal of Social Sciences Research, 2017;02(09), 88-94.

[19] Mamo, T., Tefera, T. and Byre, N. Factors influencing urban and periurban dairy producers' participation in milk value addition and volume of milk value added in Welmera Woreda, West Shewa Zone of Oromia Regional State, Ethiopia. International Journal of Livestock Production, 2014;5(9), 165-172. https://doi.org/10.5897/IJLP2013.0174.

[20] Bentham, J. An introduction to the principles of morals and legislation. Oxford: Clarendon Press, 1789.

[21] Mill, J.S. Utilitarianism. Roger Crisp (ed.). Oxford: Oxford University Press, 1861.

[22] Crimmins, J.E. and Long, D.G. (eds.), Encyclopedia of utilitarianism. London \& New York: Continuum International Publishing Group, 2012.

[23] Greene, W.H. Econometric Analysis (Seventh ed.). Boston: Pearson Education, 2012; pp. 803-806.

[24] van Dijk, B., Fok, D. and Paap, R. A rank-ordered logit model with unobserved heterogeneity in ranking capacities, 2007. URL.publishing.cur.nl/ir/repub/asset/8533/ei2007-07.pdf.

[25] National Population Commission (NPC). Official census report of South East, Nigeria. Abuja: NPC, 2006.

[26] Krejcie, R. V. and Morgan, D. W. Determining sample size for research activities. Educational and Psychological Measurement, 1970;30(3), $607-610$

[27] Onwubiko, O. F., Asmuni, A., Idris, K. and Othman, J. The causes, effects and potential solutions to the deep-rooted Niger Delta oil crisis.
International Journal of Social and Behavioral Sciences, 2013;1(6): 122-129.

[28] Starkweather, J. and Moske, A.K. Multinomial Logistic Regression, 2011. Retrieved from:

https://it.unt.edu/sites/default/files/mlr_jds_aug2011.pdf, June 18 2020 .

[29] Berry, S. Estimating Discrete Choice Models of Product Differentiation. RAND Journal of Economics, 1994;25, 242-262.

[30] Diaz-Quijano, F.A. A simple method for estimating relative risk using logistic regression. BMC Medical Research Methodology, 2012;12(14), 1-6. https://doi.org/10.1186/1471-2288-12-14.

[31] Ngore, P.M., Mshenga, P.M., Owuor, G. and Mutai, B.K Socioeconomic Factors Influencing Meat Value Addition by Rural Agribusinesses in Kenya. Current Research Journal of Social Sciences, 2011;3(6), 453-464.

[32] Berem, R.M., Obare, G.A. and Owuor, G. Is Value Addition in Honey a Panacea for Poverty Reduction in the ASAL in Africa? Empirical Evidence from Baringo District, Kenya. Contributed paper presented at the joint $3^{\text {rd }}$ African Association of Agricultural Economists (AAAE) and $48^{\text {th }}$ Agricultural Economists Association of South Africa (AEASA) conference, Cape Town, South Africa, September, 19-23, 2010.

[33] Nichter, S. and Goldmark, L. Small Firm Growth in Developing Countries. World Development, 2009;37(9), 1453-1464.

[34] Okebiorun, E.O. and Jatto, N.A. Value Addition in Cassava Processing: Evidence from Women in Ilesa West Local Government Area of Osun State. Agriculture and Food Sciences Research, 2017;4(1), 30-36.

[35] Coltrain, D., Barton, D. and Boland, M. Value added: opportunities and strategies, 2000. Available at: http://tinyurl.com/ycoxv5m9. Retrieved on 27/12/2018.

[36] Fleming, K. Value-Added Strategies: Taking Agricultural Products to the Next Level. AgriBusiness, 2005; AB-16.

[37] Kehinde, A.L. and Aboaba, K.O. Analysis of value addition in the processing of cassava tubers to "garri" among cottage level processors in southwestern Nigeria. Invited poster presented at the $5^{\text {th }}$ International Conference of the African Association of Agricultural Economists, September 23-26, Addis Ababa, Ethiopia, pp. 1-13, 2016.

[38] Adeyemo, T.A. and Okoruwa, V.O. Value Addition and Productivity Differentials in the Nigerian Cassava System. Sustainability, 2018;10, 4770; doi:10.3390/su10124770.

[39] Mkandawire, V.J. and Gathungu, H.K.B.E. Determinants of Participation in Value Addition Activities among Farmer Groups in Ntchisi District, Malawi. Journal of Economics and Sustainable Development, 2018;9(20), 122-130.

[40] Ntale, J.F., Litondo, K.O. and Mphande, M.O. Indicators of Value Added Agri-Businesses on Small Farms in Kenya: An Empirical Study of Kiambu and Murang'a Counties. Journal of Small Business and Entrepreneurship Development, 2014;2(3 \& 4), 89-101.

[41] Tsalwa S.G. and Theuri, F. Factors Affecting Value Addition to Tea by Buyers within the Kenyan Tea Trade Value Chain. International Journal of Humanities Social Sciences and Education (IJHSSE), 2016;3(2), 133-142.

[42] Harris, J.M. The Impact of Food Product Characteristics on Consumer Purchasing Behavior: The Case of Frankfurters. Journal of Food Distribution Research, 1997;28(1), 92-97.

[43] Adegbola, Y.P., Adjovi, N.R.A., Adekambi, S.A., Zossou, R., Sonehekpon, E.S., Komlan, F.A. and Djossa, E. Consumer Preferences for Fresh Tomatoes in Benin using a Conjoint Analysis. Journal of International Food \& Agribusiness Marketing, 2019;31(1), 1-21. DOI: 10.1080/08974438.2018.1469448.

[44] Madura, J. International Financial Management, $8^{\text {th }}$ edition. Andover: Cengage Learning, 2006

[45] Falola, A., Oyinbo, O., Adebayo, S.A., Jonathan, A. and Jimoh, J.O. Determinants of Value Addition to Cassava in Kwara State, Nigeria. University of Mauritius Research Journal, 2016;22, 245- 259.

[46] Admassie, A. The Political Economy of Food Prices: The Case of Ethiopia. In P. Pinstrup-Andersen (ed), Food Price Policy in an Era of Market Instability: A Political Economy Analysis. Oxford: United Nations University - World Institute for Development Economics Research (UNU-WIDER), 2015.

[47] Ismail, J.I. Influence of Market Facilities on Market Participation of Maize Smallholder Farmer in farmer organization's market services in Tanzania: Evidence from Kibaigwa International Grain Market. Global Journal of Biology, Agriculture \& Health Sciences, 2014;3(3), 181189.

[48] Gallis, J.A. and Turner, E.L. The risks of odds ratios: Relative risks are more naturally understood. BJOG: An International Journal of Obstetrics and Gynaecology, Research Method Guides, 2019;15561557. 